DOI 10.14746/ssp.2018.2.10

Joanna KAŁUŻNA

Uniwersytet im. Adama Mickiewicza w Poznaniu

\title{
Dekomunizacja przestrzeni publicznej w Polsce - zarys problematyki
}

Streszczenie: W artykule poddano analizie zjawisko dekomunizacji przestrzeni publicznej w Polsce, tak w formie inicjatyw podejmowanych w latach 1989-2016, jak i przyjętej 1 kwietnia 2016 roku ustawy - pierwszego aktu prawnego całościowo traktującego o zakazie propagowania komunizmu lub innego ustroju totalitarnego przez nazwy budowli, obiektów i urządzeń użyteczności publicznej na terytorium Rzeczypospolitej Polskiej.

Słowa kluczowe: pamięć społeczna, upamiętnienia w przestrzeni publicznej, polityka historyczna, dekomunizacja

D ekomunizacja przestrzeni publicznej w Polsce, choć według niektórych niedoskonała, bez wątpienia rozpoczęła się już w 1989 roku¹. Powołując się na kompleksowe badania Elżbiety Hałas, należy wskazać, że w latach 1989-1998 zmienione zostały nazwy 2098 ulic (Hałas, 2004, s. 132). Przypuszczać należy, że większość modyfikacji podyktowana była ich lokalizacją (centrum miasta), osobą patrona (postać oceniana na poziomie wiedzy powszechnej w sposób negatywny) czy lokalnym resentymentem (chęć przywrócenia przedwojennej nazwy ulicy). Niemniej kojarzone $\mathrm{z}$ bezpośrednim, potransformacyjnym okresem są spektakularne demontaże pomników lub ich zniszczenie - przywołać można chociażby pomnik Feliksa Dzierżyńskiego na placu Bankowym w Warszawie, Iwana Koniewa na osiedlu Widok w Krakowie czy Włodzimierza Lenina na Placu Centralnym w Nowej Hucie (Kraków). Po upływie mniej więcej 10 lat dekomunizacja przestrzeni publicznej ustała, co nie oznacza, że została dokonana. Można stwierdzić, że proces ten w naturalny sposób

1 Nadmienić jednak należy, że redefiniowanie przestrzeni publicznej jest procesem ciagłym - jego etapy miały miejsce także w okresie PRL, choć ówczesne zmiany nazw ulic oraz patronów poszczególnych obiektów czy demontaż pomników, stanowiły element szeroko rozumianej destalinizacji. 
wygasł, a pomimo pozostawienia licznych obiektów (w tym nazw ulic) o konotacji komunistycznej, lokalne społeczności zaprzestały dążyć do ich usunięcia.

\section{Status quo - obojętności, rozsądku czy niewiedzy?}

W niezdekomunizowanej przestrzeni publicznej w Polsce można odnaleźć następujące dominanty (klasyfikacja własna): pomniki braterstwa broni (rzadziej - czynu rewolucyjnego), w tym w formie czołgów, armat i innych obiektów militarnych; pomniki upamiętniające postaci lub wydarzenia związane $\mathrm{z}$ historią rozwoju ruchu komunistycznego; elementy zdobnicze prezentujące sowiecką symbolikę w obrębie cmentarzy wojennych lub miejsc pamięci; nazwy ulic, którym patronują działacze ruchu komunistycznego lub które nawiązują do rozwoju tego ruchu, jednak na poziomie wiedzy powszechnej nie wpływają na uruchomienie procesu negatywnej konotacji. Oszacowanie liczby tych wszystkich obiektów jest de facto niemożliwe, bowiem po 1989 roku nigdy ustawodawca nie wprowadził obowiązku ich ewidencjonowania, a dotychczasowe próby miały charakter naukowy i tym samym stanowią jedynie materiał szacunkowy. I tak, na przykład Dominika Czarnecka dokonała katalogizacji ,,pomników wdzięczności Armii Czerwonej”, jednak z wyłączeniem tablic pamiątkowych, popiersi, symbolicznych mogił, kamieni - czego efektem było objęcie badaniem 476 pomników (Czarnecka, 2013, s. 94-95). Odnosząc się do danych przedstawionych przez IPN, a dotyczących nazw ulic - jest ich 943, a innych obiektów, z wyłączeniem województwa mazowieckiego, 469 (Dekomunizacja). Tym samym, chociażby pomiędzy danymi przedstawionymi przez Czarnecką a Instytut Pamięci Narodowej, widać już wyraźne rozbieżności.

Problematyka dekomunizacji przestrzeni publicznej nie dotyczy tylko i wyłącznie Polski, ale wszystkich państw europejskich - o różnicach stanowi jedynie status tych państw przed upadkiem ZSRR, bliskość kulturowa, geograficzna lub zależność polityczna, a także współcześnie - charakter umów międzynarodowych zawartych przez dane państwo i Federację Rosyjską, a odnoszących się do ochrony miejsc pamięci.

Tym samym, dążenia do dekomunizacji przestrzeni publicznej w poszczególnych państwach europejskich przybierały różnorakie formy. Dla przykładu, w Polsce nigdy nie podjęto inicjatywy stworzenia miejsca, 
w którym umieszczone zostałyby „niechciane” pomniki². Odmiennie postapiono w Budapeszcie, gdzie od 1993 roku funkcjonuje Szoborpark - Park Pamięci (Mementopark), niedaleko Druskiennik, gdzie w 2001 r. otwarto Park Grūtas (Grūto parkas) oraz w Sofii - gdzie w tym samym roku zainaugurowano działalność Muzeum Sztuki Socjalistycznej, pierwotnie mające nosić nazwę Muzeum Sztuki Totalitaryzmu (Vukov). We wszystkich tych miejscach zgromadzone zostały pomniki wzniesione na terytorium Węgier, Litwy czy Bułgarii w okresie powojennym, prezentujące zarówno przywódców radzieckich, jak i lokalnych działaczy komunistycznych. Wszystkie parki mają charakter edukacyjny, choć należy nadmienić, że na ich terenie prowadzona jest również sprzedaż komercyjnych pamiątek, w tym noszących znamiona popkulturowej estetyki.

Nigdy w Polsce także pomniki przyjaźni polsko-radzieckiej, braterstwa broni, zwycięstwa nad faszyzmem czy wyzwolenia - w formie czołgów, armat lub innych obiektów militarnych, nie były przedmiotem instalacji artystycznych ${ }^{3}$. Inaczej stało się w Pradze, czego efektem jest słynny Różowy Czołg - na stałe umieszczony w Muzeum Sztuki Wojskowej w Lešanach, ale okazjonalnie transportowany do czeskiej stolicy, na przykład w 20. rocznicę opuszczenia przez wojska radzieckie Czechosłowacji (Pink). Jedynym przykładem podobnych działań w Polsce, lecz - co należy podkreślić - nawiązujących do nieobecnego już wtedy w przestrzeni publicznej obiektu, było ustawienie zminiaturyzowanej kopii pomnika Lenina w Nowej Hucie w formie „Fontanny przyszłości”, to jest neonowego przywódcy rewolucji oddającego mocz, który ma „oddemonizować Nową Hutę" (Rosyjskie).

Jako ostatni przykład działań w obszarze przestrzeni publicznej, który również nie jest tożsamy z polskimi rozwiązaniami, należy przywołać Pomnik Żołnierzy Radzieckich Berlin-Tiergarten, znajdujący się zaledwie 200 metrów od symbolu tego miasta - Bramy Brandenburskiej. Nie tylko obejmuje on znaczny obszar, ale pozostał niezmieniony od 1945 roku, co oznacza, że oprócz prezentowania tam dwóch haubicoarmat oraz dwóch czołgów T-34, odnaleźć można także godło Związku Radzieckiego czy monumentalny pomnik żołnierza Armii Czerwonej. W 2014 roku

2 Inicjatywę taką zapowiada się obecnie (luty, 2018 roku) - ma dotyczyć przeniesienia części usuniętych z przestrzeni publicznej obiektów do Muzeum Zimnej Wojny w Podborsku.

3 Niemniej wielokrotnie bywały one obiektem działań wandali, co jednak trudno uznać za konceptualną i noszącą artystyczny wyraz przemiany symbolicznej, aktywność. 
kompleks stał się obiektem szeroko zakrojonej, negatywnej kampanii dziennika „Bild” - redaktorzy wzywali wówczas niemiecki parlament do usunięcia obiektów oraz umieścili specjalny formularz petycji, którą dodatkowo czytelnicy mogli przesyłać do władz. Inicjatywa spotkała się ze zdecydowaną reakcją przedstawicieli niemieckiej klasy politycznej, także na szczeblu dyplomatycznym i odrzuceniem żądania (German).

Dotychczas w Polsce nie miały miejsca także tak zaognione spory, jak ten dotyczący usunięcia pomnika sowieckiego żołnierza w Tallinie, gdzie w 2007 roku podczas demontażu monumentu 1 osoba zginęła, ponad 40 zostało rannych, a około 300 aresztowanych (Estonia).

Z drugiej jednak strony, w wielu krajach Europy Zachodniej (na przykład Belgii, Francji, Republice Niemieckiej), znajdującym się w centrach miast arteriach patronują Karol Marks, Fryderyk Engels czy Obrońcy Stalingradu. To również niewyobrażalne w ramach polskiej polityki historycznej.

\section{„Działanie niewychowawcze, pochwała zbrodniczych ideologii”}

Próby dekomunizacji przestrzeni publicznej podejmowano wielokrotnie, a ich inicjatorem - w formule zinstytucjonalizowanej - był przede wszystkim IPN. Już bowiem w 2007 roku, ówczesny prezes Instytutu Janusz Kurtyka, skierował do 138 gmin oficjalne pisma, w których wskazywał nazwy ulic „będące formą okazywania czci i szacunku dla ideologii nazistowskiej i komunistycznej" (Komunikat IPN). Dokument spotkał się z powszechnym oburzeniem władz gmin, a w lokalnej prasie przedrukowywano przede wszystkim następujący fragment: „utrzymywanie tego rodzaju nazw w niepodległej Polsce powinno być traktowane jako działanie niewychowawcze, pochwała zbrodniczych ideologii i zdrady Ojczyzny oraz faktyczna zachęta do podejmowania działań niezgodnych z Konstytucją RP" (Instytut). Jak zostało wykazane w artykule mojego autorstwa w 2010 roku tylko 37 gmin, co stanowi niecałe 30\% adresatów, na owe komunikaty w ogóle odpowiedziało, w tym pozytywnie do treści pisma ustosunkowało się 6 gmin, 10 zapowiedziało przeprowadzenie konsultacji społecznych, 21 odniosło się do inicjatywy IPN negatywnie. Na podstawie tych danych widać skalę niechęci, czy też ignorancji wobec inicjatywy Instytutu. Co więcej, wyniki konsultacji społecznych - jeżeli takowe w ogóle zostały przeprowadzone - również nie przyniosły oczekiwanych przez prezesa Kurtykę rezultatów (Kałużna, 2010). Niemniej, 
należy podkreślić, że mieszkańcy odnosząc się negatywnie do zmian, podnosili przede wszystkim argumenty dotyczące konieczności poniesienia określonych kosztów - tak przez gminy, jak i osoby fizyczne oraz prawne.

\section{„Wybór patronów [...] wskazuje na wartości”}

Zgoła odmiennie podejście zaprezentowane zostało w 2008 roku przez Oddziałowe Biuro Edukacji Publicznej IPN w Krakowie - we współpracy z samorządem województwa małopolskiego zorganizowało ono bowiem regionalny konkurs „Patroni naszych ulic, placów, osiedli” (Informator), na którym niewątpliwie wzorowany jest jeden z dziewięciu ogólnopolskich projektów edukacyjnych IPN. Zyskał on uproszczoną nazwę „Patroni naszych ulic” i prowadzony jest w formule ciagłej. Jego głównym założeniem jest aktywizacja dzieci i młodzieży szkolnej, w tym harcerzy - to przede wszystkim bowiem te grupy dostarczają specjalne publikacje IPN, prezentujące sylwetki postaci historycznych. Adresatami publikacji są ,gospodarstwa domowe, każde firmy”, które znajdują się przy danej ulicy (Patroni). Projekt więc nie ma za zadanie nakłonić do zmiany nazwy ulicy, ale utwierdzić mieszkańców o słuszności nadanego patronatu i uświadomić ich, że „Wybór patronów przestrzeni, w której żyjemy, świadczy nie tylko o naszej wrażliwości historycznej, lecz także wskazuje na wartości, do których chcemy się odwoływać" (Patroni). Dotychczas wydano następujące publikacje: Generał August Emil Fieldorf „Nil”, Generał Leopold Okulicki „Niedźwiadek”, Rotmistrz Witold Pilecki, Błogosławiony ksiądz Jerzy Popiełuszko, Generał Kazimierz Sosnkowski, Marszałek Józef Piłsudski, Pułkownik Łukasz Ciepliński, Mecenas Władysław Siła-Nowicki, Stefan Rowecki „Grot”, Profesor Tomasz Strzembosz, Generał Władysław Anders, Generał brygady Stanisław Sosabowski, Danuta Siedzikówna „Inka”, Irena Sendlerowa, Obrońcy Poczty Polskiej w Gdańsku, Generał broni Stanisław Maczek, Obrońcy Poczty Polskiej w Gdańsku, Ryszard Kaczorowski, Wincenty Witos, Anna Walentynowicz, Stefan Korboński, Roman Dmowski, Jan Paweł II, Kazimierz Bartel, Jan Rodowicz „Anoda”, Generał brygady Antoni Chruściel, Kardynał Stefan Wyszyński Prymas Tysiąclecia, Janusz Korczak, Generał brygady Elżbieta Zawacka „Zo”, Stefan Starzyński, Marian Rejewski, Karolina Lanckorońska, Kardynał Adam Stefan Sapieha, Powstańcy warszawscy, Jan Karski (Patroni). Dodatkowo, w Bibliotece 
Cyfrowej IPN można odnaleźć także następujące tytuły, nieuwzględnione przy aktualizacji strony projektu edukacyjnego: Dziewięciu z Wujka, Ksiądz Roman Kotlarz, Jerzy Giedroyc, Major Hieronim Dekutowski „Zapora”, Stanisław Sojczyński „Warszyc” (Patroni naszych).

\section{1 kwietnia 2016 - żarty się skończyły}

Przyjęta 1 kwietnia 2016 roku głosami 438 posłów ustawa (1 poseł wstrzymał się od głosu, 21 było nieobecnych) jest pierwszym aktem prawnym całościowo traktującym o zakazie propagowania komunizmu lub innego ustroju totalitarnego przez nazwy budowli, obiektów i urządzeń użyteczności publicznej (Głosowanie). Zasadnicze założenia tej ustawy dotyczą nazw jednostek organizacyjnych, jednostek pomocniczych gminy, budowli, obiektów i urządzeń użyteczności publicznej, w tym dróg, ulic, mostów i placów - nadawanych przez jednostki samorządu terytorialnego - które nie mogą upamiętniać osób, organizacji, wydarzeń lub dat symbolizujących komunizm lub inny ustrój totalitarny, ani w jakikolwiek sposób takiego ustroju propagować (art. 1). Co istotne, za takowe uznaje się też wszystkie nazwy odwołujące się do osób, organizacji, wydarzeń lub dat symbolizujących represyjny, autorytarny i niesuwerenny system władzy w Polsce w latach 1944-1989 (art. 2). Kluczowym założeniem ustawy jest umożliwienie dokonania zmian w powyższym obszarze nawet bez aprobaty społeczności lokalnej, w tym braku zgody organów władzy jednostek samorządu terytorialnego, bowiem dokument ten gwarantuje wojewodzie - na mocy rozstrzygnięcia nadzorczego - możliwość stwierdzenia nieważności uchwały nadającej określoną nazwę, a stojącej w sprzeczności z treścią ustawy. Rozstrzygnięcie zostaje podjęte przy uwzględnieniu opinii IPN (art. 3), a z kolei w następstwie braku wydania nowej uchwały - nadającej skorygowaną nazwę, ustawa umożliwia wojewodzie wydanie zarządzenia zastępczego i zmianę nazwy ulicy (art. 3.1.) (Ustawa).

W pierwszym etapie realizacji ustawy debata publiczna zogniskowana została wokół trzech wątków: arbitralnych rozstrzygnięć wojewodów i ich ingerencji w decyzje organów jednostek samorządu terytorialnego, omnipotencji i niekonsekwencji IPN w zakresie opiniowania charakteru danej nazwy lub obiektu oraz proponowanych, nowych nazw ulic.

Będące podstawowym założeniem transformacji ustrojowej upodmiotowienie społeczności lokalnych poprzez decentralizację procesu zarzą- 
dzania państwem oraz rozpowszechnienie idei samorządności, w świetle rozstrzygnięć ustawy, wydaje się być ograniczane. Jest to szczególnie zauważalne w kontekście wcześniej podejmowanych przez IPN starań, mających na celu zachęcić organy władzy jednostek samorządu terytorialnego do dekomunizacji przestrzeni publicznej. Wobec braku oczekiwanych efektów, założenia te realizuje się obecnie poprzez arbitralne rozstrzygnięcia.

Decyzje poszczególnych wojewodów wzbudziły w latach 2016-2017 liczne protesty. Niemniej, wydaje się, że należy wyróżnić dwie odrębne, choć nierozłączne, kategorie tych sprzeciwów. Osią pierwszej jest konflikt o charakterze politycznym pomiędzy wojewodami powołanymi przez rząd Beaty Szydło (Prawo i Sprawiedliwość) a przedstawicielami szeroko rozumianych partii opozycyjnych, pełniących funkcje wójtów, burmistrzów i prezydentów miast czy tych wchodzących w skład organów stanowiących. W zdecydowanej większości nie podejmowali oni decyzji o zmianie wskazanych nazw ulic, mając pełną świadomość, że ich bierność przyczyni się do wydania przez wojewodę zarządzenia zastępczego. Tym samym, polityczna pragmatyka ${ }^{4}$ - chęć bycia niepostrzeganym przez wyborców jako dokonujący zmiany nazw ulic, doprowadziła do eskalacji konfliktów. Zrezygnowano tym samym chociażby z możliwości nadania „neutralnej” nazwy - neutralnej, gdyż wielokrotnie władze jednostek samorząa terytorialnego podkreślały, że te nadane przez danego wojewodę są nacechowane ideologiczne ${ }^{5}$.

Specyfika zmian była diametralnie różna w zależności od województwa. Forma artykułu uniemożliwia szczegółową analizę danych pochodzących ze wszystkich 16 województw, jednak dla ogólnego zobrazowania, koniecznym wydaje się wskazanie kilku tendencji. W Wielkopolsce zmieniono 51 nazw ulic, z czego aż $69 \%$ było nazwami upamiętniającymi zakończenie okupacji niemieckiej, co wśród wielu mieszkańców

${ }^{4}$ Co jednak istotne, a w przekazach medialnych całkowicie pomijane, należy raz jeszcze podkreślić, że ustawa została przyjęta w Sejmie bez głosu sprzeciwu, a wręcz przy niespotykanej zgodności wszystkich partii parlamentarnych.

${ }^{5}$ Ideologiczne nacechowanie należy utożsamiać $\mathrm{w}$ tym przypadku z perspektywą konserwatystów, w okresie najistotniejszych publicznych debat dotyczących polityki historycznej reprezentowaną przez osoby związane z krakowskim Towarzystwem Edukacyjno-Naukowym „Ośrodek Myśli Politycznej” oraz współpracowników Lecha Kaczyńskiego w okresie jego prezydentury: Marka A. Cichockiego, Antoniego Dudka, Dariusza Gawina, Dariusza Karłowicza, Leona Kieresa, Roberta Kostro, Zdzisława Krasnodębskiego, Ryszarda Legutko, Pawła Machcewicza, Tomasza Mertę, Andrzeja Nowaka, Wojciecha Roszkowskiego czy Kazimierza M. Ujazdowskiego. 
spotkało się z niezrozumieniem ${ }^{6}$. Wojewodowie popełniali również błędy, najczęściej łamiąc zapisy prawa miejscowego. Takie wskazali radni miejscy z Olsztyna - w dwóch przypadkach upłynął zbyt krótki czas od śmierci nowych patronów ulic, w trzecim nazwa ulicy jest zbyt długa. Drugie z wspomnianych zagadnień jest wyjątkowo interesującym. Bo choć w przypadku „ul. Żołnierzy 5 Wileńskiej Brygady Armii Krajowej” wojewoda warmińsko-mazurski sam dokonał korekty na „ul. 5 Wileńskiej Brygady AK" (Olsztyn), to podobne zastrzeżenia mogłyby się pojawić w przypadku zmian dokonywanych przez innych wojewodów. Bo nawet jeżeli długość nazwy nie narusza przepisów ustalonych w prawie miejscowym, to jednak ze względu na swoją złożoność może być problematyczna dla mieszkańców, na przykład: Mjr. Tadeusza Furgalskiego „Wyrwy”, Mjr. Adolfa Pilcha „Doliny”, Ppłk. Macieja Kalenkiewicza „Kotwicza”, Andrzeja Romockiego „Morro” (Dekomunizacja ulic). Zdarzały się również sytuacje dublowania nazw ulic, dla przykładu wojewoda wielkopolski ulicy 9 Maja nadał nazwę Kazimierza Spornego, choć taka kilka miesięcy wcześniej - z inicjatywy rady miasta - zastąpiła nazwę ulicy Armii Ludowej (Wojewoda).

Drugą kategorię protestów charakteryzuje po prostu niezgoda na zmiany nazw ulic lub obiektów, które są istotne symbolicznie dla społeczności lokalnej, a ich konotacje są odmienne od ustaleń pracowników IPN. Przykładem może być ul. 23 lutego lub ul. Chwiałkowskiego w Poznaniu. Pierwsza, w opinii Instytutu upamiętnia wkroczenie Armii Czerwonej i powtórne zniewolenie, jednak w świadomości poznaniaków to data nie tylko zakończenia okupacji niemieckiej, ale także dzień, w którym w walkach o Cytadelę - ostatni punkt oporu Niemców - licznie polegli cywile. Z kolei druga $\mathrm{z}$ ulic, ze względu na zlokalizowane przy niej ośrodki rekreacyjno-sportowe i miejsce wypoczynku wielu mieszkańców, nazywana była po prostu zdrobniale „Chwiałką”. Pełnej nazwy praktycznie nie stosowano, a tym samym nie kojarzono z komunistycznym patronem.

${ }^{6}$ Nazwy zawierające daty upamiętniające zakończenie okupacji niemieckiej są szczególnie problematyczne. W powszechnej świadomości mogą się bowiem odnosić do wspomnianego „zakończenia okupacji” lub „wyzwolenie spod okupacji”, a nawet występować w formie jednoczesnego skojarzenia. W następstwie pojawiają się następujące kwestie, poddawane rozlicznym dyskusjom: po pierwsze, czy działanie takie miało w ogóle charakter wyzwoleńczy czy jednak stanowiło początek nowego zniewolenia. Po drugie, kto owych działań dokonywał - wyłącznie Armia Czerwona czy także jednostki I lub II Armii Wojska Polskiego (tu ponownie - pojawia się pytania o charakter tej organizacji wojskowej) lub nastąpiło to przy współudziale (ochotniczym czy na skutek przymuszenia) osób cywilnych, mieszkańców miejscowości. 


\section{Niekonsekwencja opinii IPN}

Istotnej krytyce został poddany także brak spójności w opiniach wydawanych przez IPN. Dla potrzeb realizacji nałożonej przez ustawodawcę funkcji, Instytut stworzył między innymi ogólnodostępne katalogi: nazwy do zmiany, postaci zasłużone błędnie wiązane z normami ustawy, nazwy kontrowersyjne i błędnie wiązane $z$ normami ustawy oraz nazwy wymagające nowych uchwał wraz z uzasadnieniem. Katalogi te znacznie różnią się od siebie objętościowo. Pierwszy z nich - nazwy do zmiany, ma charakter otwarty i liczy około 150 pozycji (Nazwy do zmiany). Z racji pełnienia przez IPN także funkcji edukacyjnej (każde hasło zostało szczegółowo opisane) wydaje się, że katalog nie powinien mieć formy otwartej, a uwzględniać wszystkie postaci i wydarzenia historyczne, które zostały wskazane jako konieczne do zmiany. Być może jednak ograniczona objętość tych treści wynika z faktu, że im większa liczby nazw, tym szersze, ogólnopolskie kontrowersje. Obecnie, występują one przede wszystkim „miejscowo” i nabierają cech konfliktu lokalnego.

Wśród postaci i wydarzeń zawartych w katalogu wiele z pewnością nie budzi - na poziomie wiedzy powszechnej-jakichkolwiek skojarzeń ${ }^{7}$. Inne, co już wcześniej w artykule wspomniano, w krajach Europy Zachodniej są powszechne. Dla przykładu, w opinii IPN radzieckie zwycięstwo nad armią III Rzeszy pod Stalingradem „bezpośrednio przełożyło się na intensyfikację działań Kremla przeciwko Rzeczypospolitej Polskiej, ukierunkowanych na zerwanie stosunków międzypaństwowych i przygotowania do budowy alternatywnych struktur państwowych - w pełni zależnych od Moskwy" (Obrońców). W krajach zachodniej Europy bitwa ta jest $\mathrm{z}$ kolei utożsamiana $\mathrm{z}$ uzyskaniem znaczącej przewagi nad armią niemiecką oraz finalnym zwycięstwie sił koalicji antyfaszystowskiej w 1945 roku.

Drugi katalog - postaci zasłużone błędnie wiązane z normami ustawy liczy tylko dwie pozycje (Bolesław Limanowski oraz Stefan Okrzeja) i są one podane jako przykładowe (Postaci). Znów, wydaje się że funkcja edukacyjna IPN powinna być realizowana szerzej. Niemniej jednak, należy dodać, że w każdym innym, zgłoszonym do IPN przypadku - Instytut odpowie władzom danej gminy bezpośrednio i orzeknie, czy nazwa ulicy nie stoi w sprzeczności z założeniami ustawy dekomunizacyjnej.

7 Na przykład, uwzględniając kolejność alfabetyczną spisu: Józef Balcerzak, Stanisław Baran, Sylwester Bartosik, Franciszek Bartoszka, Tekla Borowiak, Józef Ciszewski, Tomasz Dąbala, Paweł Dylong, Stanisław Działek, Emil Dziedzic. 
Trzeci katalog - podobnie, nie jest obszerny. Zawiera jedynie sześć pozycji, określonych jako „kontrowersyjne”, a więc rekomendowane do zmiany. To ulice 1 Maja, Mieczysława Brauna, Jurija Gagarina, Marcina Kasprzaka, Komuny Paryskiej i Ludwika Waryńskiego (Nazwy). Spis jest otwarty, a decyzja o pozostawieniu bądź zmianie tych nazw należy do samorządu.

I ostatni z katalogów - wydaje się wzbudzający największe emocje - zawiera definicje nazw wymagających nowych uchwał wraz z uzasadnieniem. Pierwszym typem nazwy jest taka, która niesie pozytywne treści, będące w okresie komunizmu fałszywie interpretowanymi (np. Obrońców Pokoju), a druga - jest nazwą wieloznaczną (np. Pionierów). I tak, aby w danej miejscowości zachować ulicę Obrońców Pokoju należy w uchwale nadmienić, że nie odnosi się ona do Światowego Kongresu Intelektualistów w Obronie Pokoju zorganizowanego w 1948 roku, ale wskazać „,rzeczywistych obrońców prawdziwego pokoju, których nazwa ulicy będzie upamiętniać. Nowa uchwała może przywołać np. zabiegi władz Rzeczypospolitej Polskiej o zachowanie pokoju w roku 1939" (ul. Obrońców). W praktyce jednak takie nowe uzasadnienia dla nazw konkretnych ulic nie zawsze są pozytywnie oceniane przez IPN, co więcej, wydaje się że w zbliżonych przypadkach oceny te są zgoła odmienne.

Dla przykładu, ul. 10 Marca - dotychczas upamiętniająca w gminie Lichnowa rok 1945 i wyzwolenie spod okupacji niemieckiej, pozostała ulicą 10 Marca, ale od tej pory ,upamiętniać będzie wyzwolenia Lisewa spod 173-letniego germańskiego panowania" (Dekomunizacyjna zmiana). Fortel z kolei nie udał się z datą 22 lipca w gminie Kruklanki, gdzie radni próbowali przekonać IPN, iż w tym dniu papież Franciszek ustanowił Święto św. Marii Magdaleny (Uchwała gminy). Ich porażka była tym bardziej dotkliwa, że w Ostrołęce - w 2009 roku - z sukcesem zmieniono uzasadnienie uchwały dotyczące ulicy 22 Lipca, która obecnie upamiętnia nadanie w 1807 roku konstytucji Księstwu Warszawskiemu. W tym wypadku zaważył jednak termin przyjęcia uchwały (Ulica 22. lipca).

\section{Jak przekonać nieprzekonanych, czyli „,to nic nie kosztuje”}

Zasadniczą różnicą pomiędzy wcześniej podejmowanymi inicjatywami a rozpoczętą w kwietniu 2016 roku dekomunizacją przestrzeni publicznej jest nie tylko jej powszechny i obligatoryjny charakter, ale również po raz pierwszy uregulowano - przynajmniej w części - kwestie dotyczące 
wynikających z tego procesu kosztów. Ustawa gwarantuje bowiem, że zmiana nazwy ulicy nie ma wpływu na ważność dokumentów zawierających nazwę dotychczasową, a pisma oraz postępowania sądowe i administracyjne w sprawach dotyczących ujawnienia w księgach wieczystych oraz uwzględnienia w rejestrach, ewidencjach i dokumentach urzędowych nowej nazwy - są wolne od opłat (art. 5.1. oraz 5.2.). W praktyce jednak takich kosztów jest o wiele więcej. W przypadku przedsiębiorców, ale także wszystkich jednostek organizacyjnych, stowarzyszeń, fundacji czy urzędów to oczywiście konieczność modyfikacji elementów tworzących identyfikację wizualną (ulotki, broszury, informatory, strony internetowe i profile komunikacji elektronicznej) oraz tych będących podstawą polityki informacyjnej (szyldy, wizytówki, papier korespondencyjny i inne). Kwestią albo znacznie obciążającą budżet spółdzielni czy wspólnoty mieszkaniowej albo wpływającą niekorzystnie na aspekty wizualne, jest zmiana nazw umieszczonych na wcześniej już poddanych termomodernizacji obiektach. Często konieczna jest wymiana części zmodernizowanej powierzchni, a w przypadku braku środków - jej ewentualne przekształcenie, co stwarza widoczną różnicę w kolorze oraz strukturze. Wspomnieć należy także o kosztach dla komunikacji miejskiej czy gminnej - zmianach nazw przystanków, korektach rozkładów jazdy. Zmiany te ze względu na specyfikę przetargów publicznych oraz charakter przepisów dotyczących zamówień publicznych, mogą się znacznie wydłużyć w czasie oraz doprowadzić do chaosu lub też obniżenia estetyki.

\section{„Walka trwa" - samorządy wnoszą odwołania do WSA}

W momencie ogłoszenia ${ }^{8}$ przez wojewodów nie tylko list ulic, których nazwy ulegną zmianie, ale przede wszystkim wskazania nowych patronów, część władz samorządowych zgłosiła wyraźny sprzeciw, w niektórych miastach zorganizowano nawet obywatelskie protesty. Najwięcej emocji wzbudziły nazwy nadające ulicom, alejom czy placom imię Lecha Kaczyńskiego (lub Lecha i Marii Kaczyńskich). Lokalne konflikty wybuchły wówczas w Bydgoszczy, Gdańsku, Katowicach, Łodzi i Warszawie (Wojewoda zmieni). W wielu innych przypadkach, sprzeciwu nie budził nowy patro-

${ }^{8}$ Zadecydowano, że ogłoszenie nowych patronów ulic będzie miało miejsce 13 grudnia, co miało nadać rocznicy wprowadzenia stanu wojennego inny wymiar symboliczny oraz podkreślić istotę dokonującego się przełomu, wyjście z dotychczasowego impasu braku powszechnej dekomunizacji przestrzeni publicznej w Polsce. 
nat, ale usunięcie wcześniej obowiązującej nazwy. Władze samorządowe zareagowały w dwójnasób - albo organy stanowiące dokonały ponownego nadania nazwy ulicy albo zaskarżyły decyzję wojewody do WSA. Tak zdecydowane działania oraz niewątpliwy opór w stosunku do wdrażanych zmian, doprowadziły jednak do szybkiej nowelizacji ustawy.

\section{Nowelizacja ustawy}

Na mocy znowelizowanych zapisów ustawy jakikolwiek sprzeciw władz samorządowych wobec zmiany nazwy ulic staje się de facto bezcelowy. Bowiem, jeżeli po prostu nie podejmie działań mających na celu wykonanie treści zarządzenia wojewody, wówczas działania te zostaną zrealizowane przez administrację wojewódzką, a ich koszty zostaną przedłożone władzom samorządowym, celem pokrycia. Z kolei, wniesienie skargi do sądu administracyjnego na zarządzenie zastępcze wojewody, możliwe jest tylko i wyłącznie, jeżeli jednostka samorządu terytorialnego ,z przyczyn niezależnych” nie może dokonać zmiany nazwy. Z racji, że żadne postępowanie w tej materii jeszcze nie zostało zakończone, nie można stwierdzić czym są takowe przyczyny.

Co jednak najbardziej istotne - nowelizacja ustawy wyklucza możliwość nadania danej ulicy, której nazwa została zmieniona przez wojewodę, nowego patronatu bez zgody właśnie wojewody oraz pozytywnej opinii IPN. Trudno zatem przypuszczać, aby wojewoda nadający określoną nazwę, zgodził się następnie na jej usunięcie i zastąpienie tą, wskazaną przez władze samorządowe.

Dodatkowo, nowelizacja znacznie - bo aż o ponad pół roku - skraca możliwy czas drugiego etapu dekomunizacji, to jest usunięcia pomników, które zostały określone jako upamiętniające osoby, organizacje, wydarzenia lub zawierają daty symbolizujące komunizm, względnie inny ustrój totalitarny lub go propagują. Ostateczny termin na dokonanie tych zmian upłynie 31 marca 2018 roku.

\section{Podsumowanie}

Zważywszy na fakt, że dopiero część założeń ustawy dekomunizacyjnej została zrealizowana, należy mieć świadomość, że proces ten potrwa, a co więcej wejdzie w fazę o wiele gorętszą. Usuwanie pomników 
z przestrzeni publicznej z pewnością zrodzi wiele konfliktów, w tym tych wynikających z utraty przez lokalną społeczność źródeł dochodu z obszaru turystyki. Co więcej, jak już część władz samorządowych zapowiedziała, będą one czynić starania by poszczególne monumenty przekształcić w sposób wyłączający konieczność ich usunięcia (np. czołg-pomnik zostanie formalnie określony jako zabytek techniki). Na chwilę obecną nie można ocenić, czy takie zabiegi okażą się skuteczne, zwłaszcza jeżeli ustawa zostanie ponownie znowelizowana. Warto też zwrócić uwage na wspomniane już skrócenie terminu, w którym należy pomniki usunąć. Wcześniejsze zapisy, wskazujące na dzień 21 października 2018 roku, zostały zmienione. Być może wynikało to $\mathrm{z}$ faktu, że termin ten jest jednym z prawdopodobnych (poza 28 października oraz 4 listopada), w którym zostaną przeprowadzone wybory samorządowe. Jeżeli tak, świadczyć to może jedynie o skali konfliktów lokalnych, które nie tylko powstały w wyniku zmian nazw ulic, ale eskalować mogą w przypadku dekomunizacji innych obiektów znajdujących się w przestrzeni publicznej, a będących dla mieszkańców danego obszaru obiektami martwymi i niefunkcjonalnymi w rozumieniu teorii pamięci społecznej - przynajmniej w odniesieniu do założeń ich twórców. Taki charakter pamięci nie wyłącza bowiem możliwości zaistnienia innych relacji, opartych na sentymencie wolnym od historycznej refleksji czy lokalnego patriotyzmu.

\section{Bibliografia}

Czarnecka D. (2013), Pomniki wdzięczności Armii Czerwonej w Polsce Ludowej i w III Rzeczypospolitej, „Dzieje Najnowsze”, R. XLV, nr 4.

Dekomunizacja ulic i pomników - dziatania IPN, https://ipn.gov.pl/p1/aktualnosci /41273,Dekomunizacja-ulic-i-pomnikow-dzialania-IPN.html.

Dekomunizacja ulic w województwie mazowieckim, https://www.mazowieckie.pl/ pl/aktualnosci/aktualnosci/35054,Dekomunizacja-ulic-w-wojewodztwiemazowieckim.html.

Dekomunizacyjna zmiana na... taka sama nazwę ulic, https://plus.dziennikbaltycki.pl/ magazyn/a/dekomunizacyjna-zmiana-na-taka-sama-nazwe-ulic,12217313.

Estonia removes Soviet memorial, http://news.bbc.co.uk/2/hi/europe/6598269.stm.

German Tabloid Campaigns For Removal Of Russian Tank Memorial, Radio Free Europe Radio Liberty, https://www.rferl.org/a/russia-german-bild-tank-memorial $/ 25334566$.html.

Gtosowanie nr 136 na 15. posiedzeniu Sejmu, pkt 4. porzqdku dziennego (sprawozdanie Komisji o senackim projekcie ustawy o zakazie propagowania komunizmu 
lub innego ustroju totalitarnego przez nazwy budowli, obiektów i urzqdzeń użyteczności publicznej, głosowanie nad przyjęciem $w$ całości projektu ustawy w brzmieniu z druku $n r$ 351), http://www.sejm.gov.pl/Sejm8.nsf/agent. xsp? symbol=glosowania\&nrkadencji=8\&nrposiedzenia=15\&nrglosowania $=136$.

Grūto parkas, http://grutoparkas.lt.

Hałas E. (2004), Polityka symboliczna i pamięć zbiorowa. Zmiany nazwy ulic po komunizmie, w: Zmiana czy stagnacja?, red. M. Marody, Wydawnictwo Naukowe Scholar, Warszawa.

Informacja o działalności Instytutu Pamięci Narodowej - Komisji Ścigania Zbrodni przeciwko Narodowi Polskiemu w okresie 1 stycznia 2008-31 grudnia 2008 r. (2009), Warszawa.

Instytut Pamięci Narodowej interweniuje w Śliwicach (2008), „Tygodnik Tucholski”, nr 3, http://www.archiwum.tygodnik.pl/?o=art\&n=3010.

Kałużna J. (2010), Pamięć społeczna po transformacji systemowej - „symbole komunizmu”, ,relikty peerelowskiej przeszłości” $i$ uchwały zmieniajace ul. XXX-lecia PRL na ul. ks. kanonika Alfonsa Czwojdy, czyli katolicyzm $i$ antykomunizm jako treści ja konstytuujace, w: Politologia jako nauka? Teoria a praktyka analizy politologicznej, red. M. Krzysztofik, D. Gauza, Wydawnictwo MAjUS s.c., Zielona Góra.

Komunikat IPN w sprawie nazw ulic, placów oraz patronów i imion instytucji publicznych, będacych formq okazywania czci i szacunku dla ideologii nazistowskiej i komunistycznej.

Memento Park Budapest, http://www.mementopark.hu/.

Nazwy kontrowersyjne i błędnie wiazane z normami ustawy, https://ipn.gov.pl/pl/upamietnianie/dekomunizacja/zmiany-nazw-ulic/nazwy-ulic/nazwy-kontrowersyjne-i/38021,Nazwy-kontrowersyjne-i-blednie-wiazane-z-normami-ustawy. html.

Nazwy do zmiany, https://ipn.gov.pl/pl/upamietnianie/dekomunizacja/zmiany-nazwulic/nazwy-ulic/nazwy-do-zmiany.

Olsztyn skarży zarzqdzenia wojewody o zmianie nazw ulic, http://www.portalsamorzadowy.pl/prawo-i-finanse/olsztyn-skarzy-zarzadzenia-wojewody-o-zmianienazw-ulic, 102424.html.

Patroni naszych ulic, http://pamiec.pl/pa/biblioteka-cyfrowa/patroni-naszych-ulic.

Patroni naszych ulic - projekt edukacyjny, http://pamiec.pl/pa/edukacja/projektyedukacyjne/ogolnopolskie/patroni-naszych-ulic/12930,Patroni-naszych-ulicprojekt-edukacyjny.html.

Pink tank unveiled in Prague to celebrate liberation anniversary, http://www.telegraph.co.uk/news/newstopics/howaboutthat/8588177/Pink-tank-unveiled-inPrague-to-celebrate-liberation-anniversary.html.

Postaci zastużone błędnie wiqzane z normami ustawy, https://ipn.gov.pl/pl/upamietnianie/dekomunizacja/zmiany-nazw-ulic/nazwy-ulic/postaci-zasluzone-bledn/36810,Niepodlegajace-ustawie.html. 
Rosyjskie media oburzone, ukraińskie zachwycone sikajacym Leninem z Nowej Huty, https://www.tvn24.pl/krakow,50/rosyjskie-media-oburzone-ukrainskie-zachwycone-sikajacym-leninem-z-nowej-huty,439930.html.

Uchwała gminy Kruklanki ws. ul. 22 lipca cofnięta przez wojewodę, https://olsztyn. tvp.pl/29602669/uchwala-gminy-kruklanki-ws-ul-22-lipca-cofnieta-przezwojewode.

Ulica 22. lipca? Tak, ale nie tego, http://wiadomosci.dziennik.pl/wydarzenia/artykuly /157884,ulica-22-lipca-tak-ale-nie-tego.html.

ul. Obrońców Stalingradu, https://ipn.gov.pl/pl/upamietnianie/dekomunizacja/zmiany-nazw-ulic/nazwy-ulic/nazwy-do-zmiany/40388,ul-Obroncow-Stalingradu.html.

ul. Obrońców Pokoju, https://ipn.gov.pl/pl/upamietnianie/dekomunizacja/zmianynazw-ulic/nazwy-ulic/lista/38513,ul-Obroncow-Pokoju.html.

Ustawa z dnia 1 kwietnia 2016 r. o zakazie propagowania komunizmu lub innego ustroju totalitarnego przez nazwy jednostek organizacyjnych, jednostek pomocniczych gminy, budowli, obiektów i urzqdzeń użyteczności publicznej oraz pomniki, Dz. U. 2016, poz. 744.

Wojewoda Zbigniew Hoffmann się pomylit. Po dekomunizacji dwie takie same ulice na mapie Poznania, http://poznan.wyborcza.pl/poznan/7,36001,22787806,wojewodasie-pomylil-dwie-takie-same-ulice-na-mapie-poznania.html.

Wojewoda zmieni nazwę ulicy na Kaczyńskiego? To raczej nieodwołalne. Dopóki rzqdzi PiS, http://www.tokfm.pl/Tokfm/7,130517,22888694,wojewoda-zmieninazwe-ulicy-na-kaczynskiego-to-raczej-nieodwolalne.html.

Vukov N., The Museum of Socialist Art in Sofia and the Politics of Avoidance, http:// www.imre-kertesz-kolleg.uni-jena.de/index.php?id=361.

\section{Decommunization of the public space in Poland - an outline of the issue}

\section{Summary}

The analysis presented in the paper examines the process of decommunization of the public space in Poland. The initiatives taken between 1989 and 2016 have been described as well as the act adopted on April 1, 2016, which was the first legislative act banning the propagation of communism and other totalitarian regimes by naming buildings, objects and public utilities as a whole.

Key words: social memory, collective memory in public sphere, historical policy, decommunization 
